\title{
高感度複合光導波路のアンモニアセンサへの応用
}

\author{
阿布力孜 伊米提a,b，伊藤 公紀a * 村林 眞行 ${ }^{\mathrm{a}}$ \\ $\mathrm{a}$ 横浜国立大学環境科学研究センター（T240-8501 横浜市保土ヶ谷区常盤台 79-7） \\ b 新疆大学化学系（830046 新疆ウイグル自治区 ウルムチ市，中国）
}

\section{A Highly Sensitive Composite Optical Waveguide Applied to the Ammonia Sensor}

\author{
Abliz YIMIT, ${ }^{\text {a,b }}$ Kiminori ITOH, ${ }^{\mathrm{a}, *}$ and Masayuki MURABAYSHI ${ }^{\mathrm{a}}$ \\ aInstitute of Environmental Science and Technology, Yokohama National University (Tokiwadai, Hodogaya ku, \\ Yokohama 240-8501, Japan) \\ ${ }^{b}$ Department of Chemistry, Xinjiang University (Urumqi 830046, China)
}

Received April 5, 2001 ; Accepted July 23, 2001

\begin{abstract}
The detection of the ammonia gas is an important task in many technological fields such as industrial processes, clinical diagnosis and environmental monitoring. Here, we report on a composite optical waveguide (COWG) ammonia sensor, which is based on evanescent field adsorption. The highly sensitive element of this sensor is a polytungstic acid (PTA) film $/ \mathrm{K}^{+}$ion exchanged glass COWG, fabricated by coating the PTA film over the potassium ion exchanged glass OWG. The sensing film of indicator dye of the bromothymol blue (BTB) was coated onto the optical waveguide surface by the spin coating method. The experimental arrangement and response characteristics are reported in detail. The sensor has a short response time, highly sensitivity, and detection limit is $1 \mathrm{ppb}$.
\end{abstract}

Key Words : Composite Optical Waveguide, Bromothymol Blue Thin Film, Ammonia Sensor

\section{1 緒 論}

化学センサは，新しい計測技術として環境保全，農業，工 業，医療及び食品などの分野で用いられている ${ }^{1)}$. 特に，光 技術に基づいた化学センサは，電磁気的ノイズに強く，精密 な測定が可能で, 光ファイバーとのマッチングが良い.これ らに加えて光導波路では, 装置のコンパクト化ができるとと もに，高感度化できる可能性がある2)，光導波路による物質 センシングとしては，光導波路表面に適当なセンシング部分 を固定し，光導波路表面付近にある生化学物質とセンシング 部分との相互作用によるエバネッセント波の吸収を利用する のが基本である．光導波路のセンシング部分は，化学的な信 号を変換する感応層である.

最近, 光導波路のバイオ・ケミカルセンサへの応用が注目 され，色素を感応層とする高感度アンモニアセンサが開発さ れた ${ }^{3-5)}$. 例えば，R. Klein らはゾルーゲル法で作製した多 孔性 $\mathrm{SiO}_{2}$ 薄膜中に $\mathrm{pH}$ 指示薬色素を混合し，これをガラス 光導波路上に感応層としてコートすることにより, $1 \mathrm{ppm}$ までのアンモニアを容易に検出した ${ }^{4}$ 。我々の研究室では， $\mathrm{pH}$ 指示薬色素ブロムチモールブルー（BTB）と酢酸セルロ スを混合した膜を $\mathrm{Ag}^{+} / \mathrm{K}^{+}$イオン交換ガラス複合光導波路上

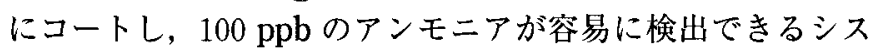
テムを開発した ${ }^{5)}$.このデバイスは，他 ${ }^{6-8)}$ の色素を用いた オプテイカルアンモニアセンサより感度が高く, 応答速度も 速い.
複合光導波路では，基板と薄膜導波層との屈折率差が大き いほど，その表面感度が高〈なる ${ }^{2)}$. 本研究では, アンモニ アセンサ5)を改良するために, 高感度かつ安価で, 作製容易 なポリタングステン酸 (PTA) 膜/ $\mathrm{K}^{+}$イオン交換ガラス複合 光導波路 $\left.{ }^{9}\right) を$ 用いた. ブロムチモールブルー（BTB）を感応 層としてPTA 導波層上に直接薄膜化することを試み, 感度 が高く，1 ppbまでのアンモニアを検出できた。本報では， $\mathrm{PTA}$ 膜 $/ \mathrm{K}^{+}$イオン交換ガラス複合光導波路のアンモニアセ ンサへ応用について述べる.

\section{1 複合光導波路の作製}

\section{2 実 験}

金属タングステンと過酸化水素水を反応させ, 過酸化ポリ タングステン酸 (PPTA) を得た10). 乾燥したPPTA 試料 $0.15 \mathrm{~g}$ を $1.0 \mathrm{~cm}^{3}$ 蒸留水に溶解し, スピンコーティング法に

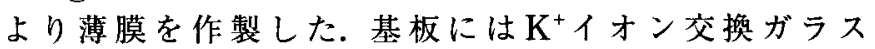
$\left(400^{\circ} \mathrm{C}\right.$ に設定した電気炉中で溶解した硝酸カリウム溶液中 に，市販のスライドガラスを 30 分間浸漬した）を用いた。 PPTA 膜は $120^{\circ} \mathrm{C} て ゙ 90$ 分間加熱し (PPTA膜中の過酸化 物基が脱離しポリタングステン酸 PTAに変わる), 膜硬化を 行った。水でエッチングすることにより, Fig.1に示すよう に, PTA膜の両端にテーパー部分（長さ1〜2 mm）を持つ ストライプ状（幅 5〜 7 mm）の PTA膜/ $\mathrm{K}^{+}$イオン交換ガラ ス複合光導波路を作製した ${ }^{9}$. 


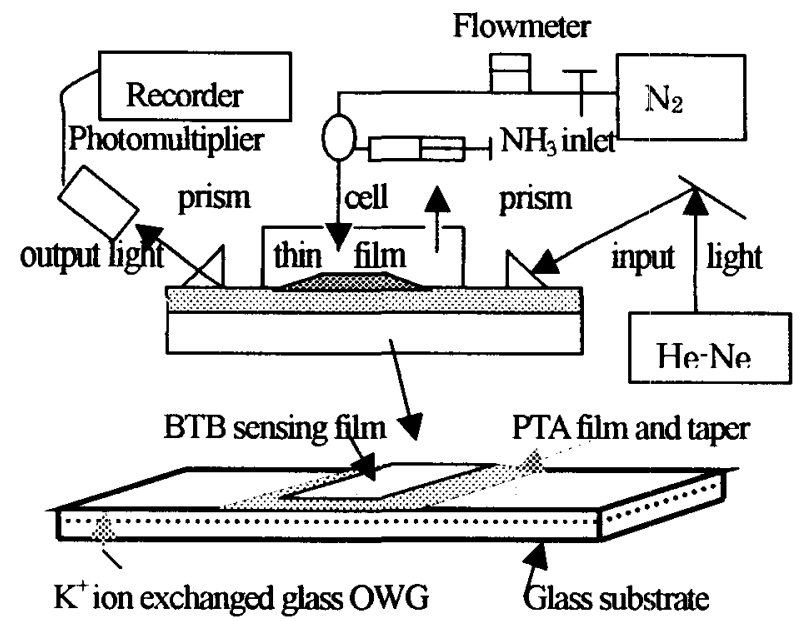

Fig. 1 BTB dye doped PTA film $/ \mathrm{K}^{+}$ion exchanged glass composite optical waveguide (COWG) and schematic diagram of COWG gas sensor system.

\section{2 センシング膜の作製}

Fig. 1 に示すように, PTA 導波層上にBTB を薄膜化して 固定した，BTB を薄膜化するには，BTBのエ夕ノール溶液 $\left(1 \times 10^{-3} \mathrm{~mol} / \mathrm{dm}^{3}\right)$ を用い，スピンコーティング法 $(2000$ rpm）によって行なった.

BTB 薄膜（酸性型）と水酸化ナトリウムを加えたエ夕， ール溶液（塩基性型）の吸収スペクトルは, 分光光度計 (Hitachi，220A 型）を用いて测定した．BTB 及びPTA 膜 の厚さはエリプソメトリー（日本分光社製 M-220 型）を 用いて $(632.8 \mathrm{~nm})$ 測定した。

\section{3 測 定}

Fig. 1 に示すように，プリズム結合法を用い，波長 632.8 $\mathrm{nm}$ の He-Ne レーザ光を PTA 膜/ $\mathrm{K}^{+}$イオン交換ガラス複合 光導波路に導入した，光導波路とプリズムの密着には，屈折 率 1.74 のヨウ化メチレンを使用した. 感応層とする BTB 膜 とアンモニアを十分接触させるために, $2 \times 1 \times 1 \mathrm{~cm}^{3}$ のセル を用いた．窒素をキャリヤーガスとして $50 \mathrm{~cm}^{3} / \mathrm{min}$ の流速 でフローセルに入れた。

アンモニアガスは, 純窒素ガスで置換した $1000 \mathrm{~cm}^{3}$ の標 準真空瓶中で一定量のアンモニア水 $(28 \%)$ を気化させるこ とによって得た．濃度はアンモニア検知管（ガステック社 製）を用いて再確認した後，純窒素ガスで置換した 100 及び $1000 \mathrm{~cm}^{3}$ の数個の標準真空瓶で順々に希釈し，低濃度のア ンモニアを用意した。この他に，注射器ガス希釈法11,12)も用 いた．検知管で濃度を確認したアンモニアをガラス注射器 (体皘 $50 \mathrm{~cm}^{3}$ ) 中に $5 \mathrm{~cm}^{3}$ 吸い込んだ後, 体積 $50 \mathrm{~cm}^{3}$ にな るまで純窒素ガスを吸い达んだ．30〜60秒たつと混合ガス はガラス注射器中に均一に拡散し、アンモニアの濃度が 10 倍に薄まる. 上記の方法を用いて $10 \mathrm{ppm} \sim 1 \mathrm{ppb}$ 濃度のア

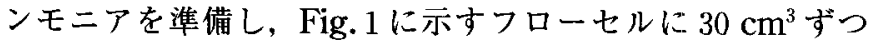
注入して測定を行なった。

\section{1 BTB 膜と複合光導波路}

\section{3 結果と考察}

BTB は, 酸性型 $(\mathrm{pH}=6.0)$ で黄色, 塩基性型 $(\mathrm{pH}=$ 7.6）で青色を示す.酸性型の BTB 膜 (a) と水酸化ナトリウ 厶を加えた塩基性（薄膜化はできない）エタノール溶液(b)

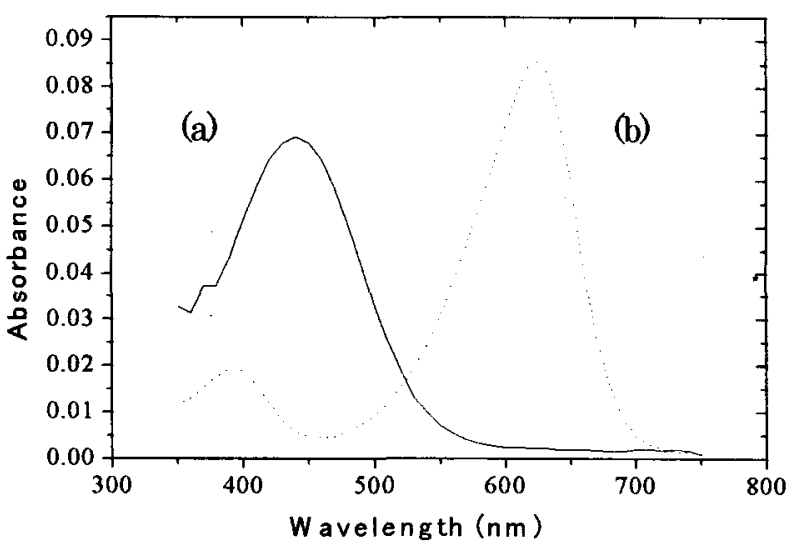

Fig. 2 The absorbance spectrum of bromothymol blue in (a) acidic state thin film and in (b) basic state solution.

との吸収スペクトルを Fig. 2 に示す。塩基性型 BTB の最大 吸収波長は $624 \mathrm{~nm}$ で, 酸性型はこの付近で光吸収を示さな い.（BTB 膜にアンモニアをさらした後，膜からアンモニア 分子の脱離が速くて，その吸収スペクトルは得られなかっ た.）

$\mathrm{PTA}$ 膜 $/ \mathrm{K}^{+}$イオン交換ガラス複合光導波路にモニター光 （632.8 nm）を導入すると，導波光は，PTA 膜の両端に設け たテーパー部分によって， $\mathrm{K}^{+}$イオン交換導波層と薄膜導波 層との間で遷移する．導波層中を伝わる光は，その表面に波 長の程度だけしみ出して (エバネッセント波) いる2゙ので, アンモニアが存在すると，BTB 膜は黄色から青色に変わり， 波長 $630 \mathrm{~nm}$ 付近の光を強く吸取する. 従って, BTB は波 長 $632.8 \mathrm{~nm}$ の He-Ne レーザ光を光源とする光導波路に基づ いたアンモニアセンサのセンシング部分には最適な材料であ ると思われる。

\section{2 センサの応答と感度}

このセンサの応答結果を Fig. 3 に示す.フローセルに窒素 ガスを流すと，導出光強度は一定であった。アンモニアを注 入すると導出光強度が急に減少した. BTB とアンモニアの 反応は可逆的であるため, 感応層 (BTB) からアンモニア

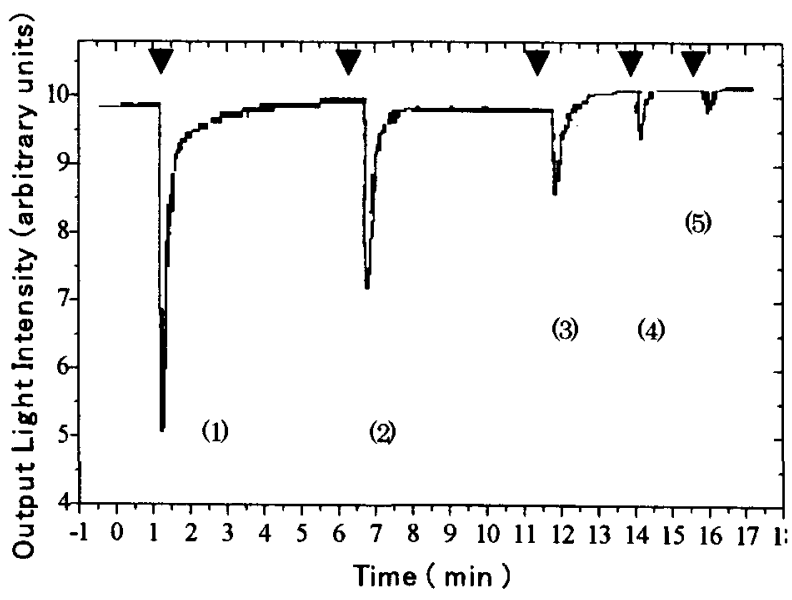

Fig. 3 The results of ammonia gas testing. The concentration of ammonia gas is: (1) $10 \mathrm{ppm}$, (2) $1 \mathrm{ppm}$, (3) $100 \mathrm{ppb}$, (4) $10 \mathrm{ppb}$, (5) $1 \mathrm{ppb}$. Arrows show the injected ammonia gas into the flow cell. 
分子の脱離に従って, 導出光強度はすぐ元のラインまで戻り, 可逆的に応答した. また, 導出光強度の変化はアンモニアの 濃度に依存し, $1 \mathrm{ppb}$ までのアンモニアを検出できた。

標準真空瓶及び注射器で希釈したアンモニアを用いて, 別々に行なった実験では, 光導波路での応答には大きな差異 が見られなかった。この二つの方法とも極めて低濃度の気体 を得るには簡単で，信頼性の高い方法11であると思われる.

本センサの感度は, $\mathrm{Ag}^{+} / \mathrm{K}^{+}$イオン交換ガラス複合光導波 路に基いたアンモニアセンサ5)より 100 倍も高い。これは， 用いた PTA 膜/ $\mathrm{K}^{+}$イオン交換ガラス複合光導波路の表面感 度が高い9)のと, BTB を直接導波層上に薄膜化したためで あると思われる。また，作製した BTB 膜表面にアンモニア 蒸気を吹きかけると, 膜全体が青色に着色し, すぐ元の色に 戻ることは肉眼でも観察できた。これは，BTB 膜の表面だ けでなく膜内部でも着色反応が起こり，光を吸収することを 示唆している。これに従って，エバネッセント波の吸収が大 きくなり，七ンサの感度が高くなったと思われる。また，そ

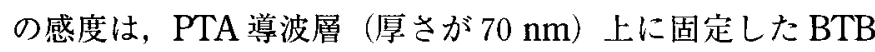
膜の厚さに敏感であり，その最適化が重要である. BTB 膜 の厚さは $35 \mathrm{~nm}$ より厚く $(38.1 \mathrm{~nm}, 45.6 \mathrm{~nm}, 57.0 \mathrm{~nm})$ す ると，導波光の散乱損失が大きくなるので，導波層と BTB 層での光の減衰が大きくなり, 導波光を導出できなかった。 BTB 膜の厚さが 20〜30 nm のとき，作製したデバイスはア ンモニアに対して比較的高い感度を示した.この厚さは, 本 デバイスの感応層として, 最適厚さであると思われる。この 光導波路は, 室温で 3 週間以上放置しても, 感度の低下は見 られなかった。

\section{3 再現性と選択性}

光導波路での吸光度は, $A b s=I o g\left(\mathrm{I}_{\mathrm{N} 2} / \mathrm{I}_{\mathrm{NH} 3}\right)$ 式によって 求めた. 式中 $\mathrm{I}_{\mathrm{N} 2}$ は, フローセルに純窒素ガスを流すときの 導出光強度で, $\mathrm{I}_{\mathrm{NH} 3}$ は, アンモニアを注入した後, 導出光強 度が減少した最低点の強度である。アンモニア濃度と光導波 路での吸光度の関係を Fig. 4 に示す.アンモニア濃度が 10 $\mathrm{ppm} \sim 1 \mathrm{ppb}$ の範囲では, 光導波路での吸光度とアンモニア 濃度の関係は直線であった。同じ光導波路を用いて繰り返し 行った測定では，プリズム結合法を用いたため, 吸光度の再 現性に少しばらつきがあった。プリズム結合法の代わりに回 折格子結合法を用いれば，セン开の定量的再現性が高くなる と思われる。

本デバイスは指示薬色素膜の $\mathrm{pH}$ 変化を用いたので，アン モニア以外，他の塩基性ガスにも応答する。これを解決する ためには，選択性膜を検討し改良する必要がある．酸性型の $\mathrm{BTB}$ は波長 $630 \mathrm{~nm}$ 付近の光を吸収しないため，フローセ ルに強い酸性ガス（塩酸蒸気）を注入したとき, 導出光強度 は変化しなかった. 従って, $\mathrm{CO}_{2}$ と $\mathrm{NO}_{\mathrm{x}}$ など酸性ガスに刘 しても応答しないと思われる。

\section{4 湿 度}

試料として用いたアンモニアは, アンモニア水を気化させ ることによって得られたので，含まれた水蒸気は少なくとも アンモニア濃度の 2.5 倍である.アンモニアと指示薬の反応 式4)考えると, 試料中の水蒸気はアンモニアとBTBとの 反応には十分であると思われる. BTB 膜は水に弱いため, フローセルの湿度を高くすると BTB 膜が劣化し, センサの 感度が低下してしまう，BTB 膜表面に保護膜を作製できれ ば，湿度に対する安定性が高くなると思われる。

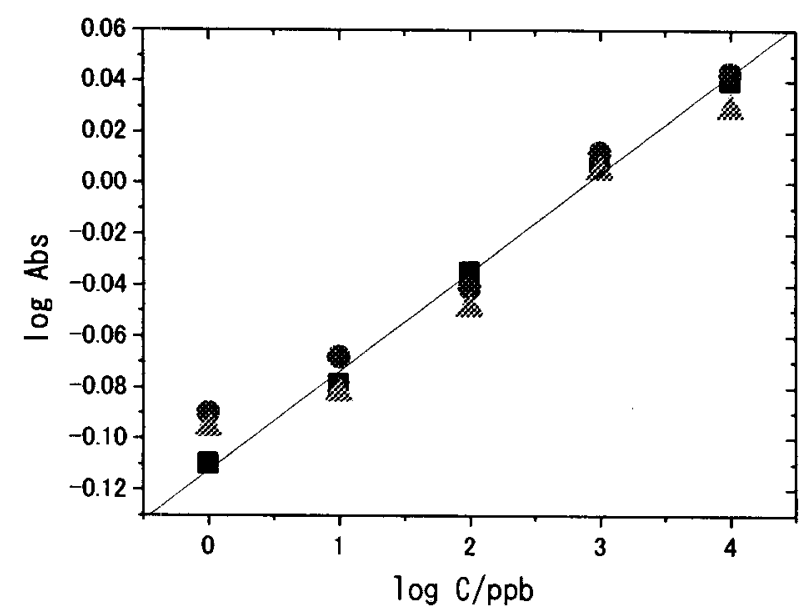

Fig. 4 Relation between the absorbance of BTB-PTA film $/ \mathrm{K}^{+}$ ion exchanged glass COWG and the concentration of ammonia gas. The experiment results of using same device and method (O) 1st, ( $\mathbf{(})$ 2nd, (A) 3rd.

\section{4 結 論}

我々は，BTB が溶液法で薄膜化できることを発見し，こ れを感度が高いPTA 膜/ $\mathrm{K}^{+}$イオン交換ガラス複合光導波路 の感応層として, 高感度アンモニアセンサを構築した。 $\mathrm{BTB}$ 膜の厚さを最適化し, $1 \mathrm{ppb}$ 濃度のアンモニアを検出 できた。

このシスデム高感度, 低コストと容易に作製できる点で は優れているが，七ンサとして実用化するためには，応答の 定量的再現性と BTB 膜の湿度に対する安定性などを改良す る必要がある。

\section{文 献}

1) N. Yamazoe, Electrochemistry, 68, 1020 (2000), (in Japanese).

2）伊藤公紀，機能材料，14，15（1994）；化学工業，44, 859 (1993).

3) J. F. Guiiliani, H. Wohlteen, and N. L. Jarvis, Opt. Lett., 8, 54 (1983).

4) R. Klein and E. Voges, "Proceedings of the Symposium on Chennical Sensor," ed by M. Butler, A. Ricco and N. Yamazoe, The Electrochem. Soc. Proc., (1993), Vol. 93-7, p.89.

5) X-M. Chen, K. Itoh, M. Murabayashi, and C. Igarashi, Chem. Lett., 1996, 103.

6) S. Muto, A. Ando, T. Ochiai, H. Ito, H. Sawada, A.

Tanaka, Jap.J. Appl. Phys., 28, 125 (1989).

7) Q. Zhou, D. Kritz, L. Bonnell, and Geoge H. Sigel, Jr., Applied Optics, 28, 2022 (1989).

8) C. Malins, T. M. Butler, and B. D. MacCraith, Thin Solid Films, 368, 105 (2000).

9) A. Yimit, K. Itoh, Z. M. Qi, and M. Murabayashi, Electrochemistry, 69, 182 (2001), (in Japanese).

10) K. Itoh, T. Okamoto, S. Wakita, H. Niikura, and M. Murabayashi, Appl. Organometal. Chem., 5, 295 (1991).

11) L. M. Webber and G. G. Guibault, Anal. Chem ., 48, 2244 (1976).

12) J. Hlavay and G. G. Guibault, Anal. Chem., 50, 1044 (1978). 